\title{
Application of Flipped Classroom Combined With OBE Concept in College English Course
}

\author{
Zhaodan Yang* \\ Applied Foreign Languages College of Eastern Liaoning University, No.325 Wenhua Road, Yuanbao District, Dandong, \\ Liaoning Province, China \\ *Corresponding author
}

\begin{abstract} college English teaching reform will be discussed in the paper.

\section{INTRODUCTION}

In traditional college English classroom teaching mode, the teacher is still the center of the whole class, which aims to impart knowledge, ignoring the vivaciousness of the students. Such mode is not conducive to cultivate students' independent thinking and innovation ability. Furthermore, it can't meet the demand for applied talents training mode of characteristic connected with social realistic requirements and innovative talents training in applied undergraduate universities. Under the background of mobile technology highly developed in the new era, college English teachers must change, the education concept, explore new teaching methods, improve the quality of teaching in order to enhance students' learning, analysis and innovation ability.
\end{abstract}

With the sustainable development of science and technology, the integration between information technology and education is increasingly deepening, China's education sector advocated that education should be developed in the direction of informatization. Under this background, the flipped classroom concept was put forward and gained the recognition from both teachers and students. As a new teaching method, it enables students to study independently. Meanwhile, the OBE concept also arises at the historic moment, which can improve the students' independent ability to solve the problem, fully meeting the requirements of modern education. Based on this, the OBE concept and flipped classroom will be analyzed, and their application in

Keywords: Flipped classroom, OBE concept, College English course, Teaching mode

\section{FLIPPED CLASSROOM AND OBE CONCEPT}

\subsection{Flipped Classroom}

Flipped Classroom, which is also called "inverted classroom", refers to the time readjustment of inside and outside the classroom, so that the decision of how to learn is transmitted from teachers to students. In this kind of teaching mode, the students are able to concentrate more on the initiative of project-based learning, common on the localization and the challenges of globalization and other world problems, to gain a deeper understanding. Students can watch video in the class through lectures, listen to podcasts, enhanced e-book reading function such as a variety of flexible ways to complete autonomous learning, can also discuss with other classmates in the network, can at any time to refer to the materials they need. Teachers can also have more time to communicate with everyone. After class, students plan what they will learn, learning rhythm, style, and present the way of knowledge, the teachers' teaching method and the collaboration method are used to meet the needs of students and make them learn personally, the goal is to make students obtain more real learning through practice

\subsection{OBE Concept}

OBE concept is mainly based on the education system of all content, clearing the ultimate goal of learning, so that the students can make continuous efforts and struggle for this purpose, and finally achieve success. In the process of concrete implementing, the following conditions are usually needed: ensuring all the students are in accordance with the appropriate way to success; the success experience can greatly stimulate students' learning enthusiasm and make them get more success; finally, the teacher is responsible to judge whether the students have the key to the success, and help students to design study plan and scheme, etc.

\subsection{Application Significance}

As for OBE concept, because it has a variety of forms, different schools can combine their own development situations to apply the proper teaching. Integrating OBE 
concept and flipped classroom into college English teaching can provide great development motives for the development of English talents, making the students' innovation ability, memory ability and understanding ability all received a significant boost.

Because college students' enthusiasm of learning English is gradually reducing, while working out teaching plan, the teachers should not only meet the requirements of the relevant teaching effect, but consider how to improve students' learning enthusiasm. Therefore, adopting the OBE concept and flipped classroom can set different targeted teaching goals, in a gradual manner, check students' learning teaching result of each stage, helping students to compensate and solve the problems in time, so that the students can obtain greater motivation with the help of the teachers.

\subsection{Application of Flipped Classroom and $\mathrm{OBE}$ in College English Course}

Based on OBE concept and flipped classroom, making full use of the positive role of the modern education technology, perfecting the existing teaching strategy combined with the teachers and students' practical situation in our country, these are the significances to promote the teaching model reform in our country. Concept of this new type of teaching learning in college English teaching is mainly reflected in three aspects: before class, in class and after class.

\subsection{Learning before Class}

The process of knowledge learning before class mainly includes producing teaching video, resolving revision problems. English teaching videos can greatly promote students' learning, which are generally produced by teachers themselves. They can be also obtained by using the relevant teaching resources on the Internet. In the class, the teacher explores some questions for students to discuss after watching the video. The detailed steps are as follows:

First of all, ensuring the pre-class assignments are consistent with in-class video;

Secondly, homework should be divided into "have to do" and "choose to do", the teacher chooses the topic quantity with appropriate control, the students solve them in the form of group discussion, or independent thinking, eventually students upload the problem solving result to "flipped classroom", the teacher corrects them online.

\subsection{Knowledge Internalization in Class}

In college English class, the teacher should help the students internalize what they learned.

\subsection{Clearing up What Will Be Taught}

The teacher should ensure that what will be taught can strike a chord to the students, or encourage students to pose questions. In cloud computing class, the student's personality strengths can be played. Combining English teaching content with life practice can internalize students' knowledge on a largest scale.

\subsection{Carrying out the Target}

The target should be carried out after clearing up what will be taught and setting the goals, which belongs to the stage of defining questions. The targets should be defined after collecting group members, then combining OBE concept with flipped classroom enables students to understand these questions promptly in short time through collaborative learning and teachers' guidance.

\subsection{Exploring Autonomously}

The teachers should guide students to independently solve problems that they encountered in the English learning process to cultivate their autonomous learning abilities. For example, the topic of unit 7 of volume 4 of New Horizon College English is "the coming energy crisis", the teacher can assign students to search for the information about "renewable energy and non-renewable energy", and think of the questions about "how to save energy?", "what are the solutions to solving energy problems?" and so on. The teacher can divide the whole class into 4-5 groups and organize them to communicate with each other to discuss questions. In the process of discussion, students will get knowledge related to energy and energy crisis, meanwhile, they can learn how to use the words related to the topic.

In general, the group leader should be asked to choose a member to share the opinions of discussion in their own way. If the reporter can't express himself/herself freely, the teacher should give him/her proper guidance, inspire the thinking, encourage students to speak more in class. Meanwhile, teachers should have enough patience and be confident to students, seek for proper opportunity to instruct students for their autonomous learning in order to achieve twice the result with half the effort.

\subsection{Consolidating Knowledge after Class}

Summary and evaluation are very important in teaching activity parts in college English teaching. In general, when the main contents of course learning finished, teachers need to summarize and evaluate the whole lesson. At the same time, in the process of summary, the teachers and students should also be together to think and reflect, helping each other to make up the shortcomings so as to become more perfect in the constant reflection. In addition, the guiding 
ideology in the class of OBE concept combined with flipped classroom should be OBE concept, teachers should pay attention to the students' ability improvement. Furthermore, flipped classroom will attach more importance to the evaluation of learning effect, and show them in the form of file.

In the new era, the birth of the new technology such as Internet, multimedia and cloud computing provides great convenience for college English classroom teaching, making classroom reflection becomes more diverse. For instance, in learning the topic-related words in unit 7 about "energy crisis", if students are not fully grasp the use method, the teachers should carry on the feedback: the reason is whether there are too many teaching videos, whether the teaching materials are too difficult, whether the students grasped the key points accurately, etc. And in the subsequent teaching adjustment, teachers should make every effort to get more notable teaching effect.

From the foregoing, the implementation of the flipped classroom can not only fully show the students' learning situation, but also can make teachers think of the root source of students' learning problems in order to avoid the same mistake, refine on the teaching, adequately implement and carry out the OBE concept, which can further promote application effect of the flipped classroom.

\section{CONCLUSION}

To sum up, under the background of the gradual teaching reform in our country, college English teaching reform has become the trend of the times. Under the modern education requirements, OBE concept should be actively combined with flipped classroom to jointly be applied to college English teaching, making the subject status of students in learning respectful, boosting students' autonomous learning ability significantly. By summary and reflection, teachers' teaching experience will be richer than before, their teaching activities will be more vivid than before. Thus, the application of OBE concept combined with flipped classroom has played a great role in promoting the development of college English teaching reform.

\section{ACKNOWLEDGEMENTS}

This research was financially supported by the Academic Administration of Eastern Liaoning University.

\section{REFERENCES}

[1] Guan-ying Xing, Ying Chen. Exploration and Reflection of Viewing, Listening and Speaking Course of College English and Vocational English---Based on the
Concept of Flipped Classroom [J]. Vocational Education Forum, 2017, (5): 78.

[2] Gui-chi Yuan. Exploration of College English Flipped Classroom Teaching Reform Based on APP [J]. Science and Fortune, 2017, (31).

[3] Yue-ying Yao. College English Teaching Innovation Practice Based on Flipped Classroom Concept in Big Data Era [J]. Northern Literature, 2017, (8): 176. 